\title{
Media Sosial Sebagai Strategi Promosi Kesehatan Reproduksi Pada Remaja
}

\author{
Qory Tifani Rahmatika ${ }^{1}$, La Ode Abd Rahman ${ }^{2}$ \\ ${ }^{1}$ Mahasiswa Program Pasca Sarjana Peminatan Komunitas, \\ Fakultas Ilmu Keperawatan Universitas Indonesia. \\ Korespondensi penulis, e-mail: fanirahmatika@gmail.com \\ ${ }^{2}$ Dosen Fakultas Ilmu Keperawatan, Universitas Indonesia
}

\begin{abstract}
ABSTRAK
Healthy People 2020 menjadikan kesehatan reproduksi sebagai indikator kesehatan utama untuk kelompok usia remaja. Dengan pengguna aktif di Indonesia mencapai 130 juta dan sebagian besar adalah kelompok usia remaja, media sosial berpotensi digunakan sebagai sarana promosi kesehatan reproduksi dalam meningkatkan pengetahuan, sikap, dan perilaku kesehatan reproduksi pada remaja. Tujuan dari studi literatur ini yaitu menelaah pengaruh media sosial sebagai metode promosi kesehatan reproduksi pada remaja. Studi literatur dipilih sebagai metode dalam penulisan ini dengan mengumpulkan literatur dari database ProQuest, Science Direct, dan Sage Journals. Literatur yang dipilih adalah jurnal full text berbahasa Inggris. Hasil dari studi literatur ini yaitu beberapa studi menggunakan media sosial sebagai strategi intervensi tunggal maupun kombinasi dengan intervensi yang lain dalam melakukan promosi kesehatan reproduksi pada remaja. Studi menunjukkan hasil yang efektif dari media sosial sebagai media promosi kesehatan untuk meningkatkan pengetahuan, sikap, dan perilaku kesehatan pada remaja yang berkaitan dengan kesehatan reproduksi. Disimpulkan bahwa media sosial memiliki keefektifan untuk digunakan oleh tenaga kesehatan termasuk perawat sebagai strategi promosi kesehatan reproduksi pada remaja.
\end{abstract}

\section{Kata Kunci: Media Sosial, Promosi Kesehatan, Kesehatan Reproduksi Remaja}

\section{LATAR BELAKANG}

Media sosial dan komunitas online telah menjadi saluran komunikasi yang penting bagi remaja di era saat ini (Todaro et al, 2018). Media sosial mengacu pada pesan teks, blog, situs video, forum, wiki, jejaring sosial, dan lainnya (Byron, Albury, \& Evers, 2013). Teknologi berbasis website dan aplikasi ini dapat digunakan untuk menjangkau populasi secara luas (Pascoe, 2011). Dari laporan berjudul "Essential Insights Into Internet, Social Media, Mobile, and E-Commerce Use Around The World" yang diterbitkan tahun 2018, dari total populasi Indonesia sebanyak
265,4 juta jiwa, pengguna aktif media sosialnya mencapai 130 juta dengan pengguna internet terbanyak berada pada umur 15-19 tahun.

Penelitian menunjukkan bahwa media sosial memiliki dampak positif maupun negatif pada status kesehatan remaja. Penggunaan media sosial pada populasi remaja memiliki risiko termasuk diantaranya cyberbullying, kesehatan mental, sexting, dan masalah privasi. Namun jika digunakan secara bijak, maka media sosial dapat meningkatkan peluang untuk kolaborasi, komunikasi, sarana promosi kesehatan, dan juga penyediaan akses informasi kesehatan 
yang penting bagi remaja seperti kesehatan reproduksi (Guinta \& John, 2018). Selain itu remaja memiliki kebebasan dan anonimitas untuk berbagi pengalaman dan memperoleh informasi. Kemudahan, kecepatan, dan keterjangkauan geografis dari jejaring sosial merupakan tantangan besar sekaligus harapan dalam hal promosi kesehatan pada remaja (LelutiuWeinberger et al, 2015).

Salah satu masalah kesehatan yang penting untuk diperhatikan pada remaja, dan dalam strategi penanganannya ditargetkan menggunakan media digital adalah kesehatan reproduksi. Bahkan Healthy People 2020 telah menjadikan kesehatan reproduksi sebagai indikator kesehatan utama untuk kelompok usia remaja. Kerentanan remaja didasarkan perilakunya yang impulsif, mengambil risiko, dan mencoba hal yang baru serta tidak didukung dengan akses informasi dan keterlibatan sosial (Erin et al, 2019). Setiap tahunnya, dilaporkan 19 juta kasus infeksi menular seksual pada remaja usia 1524 tahun di Amerika Serikat (Dunne et al, 2014).

Hal ini juga menjadi perhatian utama di Indonesia. Berdasarkan survei yang dilakukan oleh SDKI tahun 2017 pada remaja belum menikah dengan kategori umur 15-24 tahun didapatkan rata-rata remaja berpacaran mulai umur 15-17 tahun. Tren perilaku pacaran yang mengarah pada kontak seksual meningkat di angka 30\% untuk wanita dan $21 \%$ untuk pria. Rata-rata remaja telah melakukan hubungan seksual pra-nikah di umur 17 tahun. Perilaku seksual pranikah berakibat pada kehamilan yang tidak diinginkan, yaitu sebanyak $16 \%$ pada wanita usia 15-19 tahun. Hal ini juga berakibat pada meningkatnya penderita HIV dan IMS. Berdasarkan laporan Kemenkes
(2017), jumlah penderita HIV hingga tahun 2017 berada di angka 48.300 penderita dengan $3,6 \%$ berada di usia 15-19 tahun dan $17,1 \%$ berada di usia 20-24 tahun.

Queiroz et al (2011) dalam penelitiannya menyebutkan bahwa profesional kesehatan mengalami kesulitan dalam mengembangkan kegiatan yang membangkitkan perhatian publik dan memotivasi remaja untuk terlibat dalam program layanan kesehatan. Sebagai media yang populer dan sering digunakan oleh remaja di seluruh dunia, dalam hal ini media sosial berpotensi untuk digunakan dalam sarana promosi kesehatan reproduksi pada remaja (Pfeiffer, 2014). Jumlah penelitian mengenai penggunaan media sosial dalam kesehatan reproduksi remaja telah meningkat. Namun dibutuhkan tinjauan literatur terbaru terkait penggunaan media sosial yang spesifik pada upaya promosi kesehatan reproduksi pada remaja.

\section{TINJAUAN LITERATUR}

\section{Social Media \& Sexual Health Promotion}

Ressler \& Glazer (2011) mendefinisikan media sosial sebagai alat berbasis internet (Internet-based Tools) yang membantu pengguna untuk terhubung, berkolaborasi, dan berkomunikasi dengan orang lain secara real time. Media sosial mengubah paradigma komunikasi dari model bertatap muka menjadi model aplikasi berbasis web. Fungsi unik ini menjadikan media sosial berpotensi menjadi media yang berguna untuk memberikan intervensi promosi kesehatan terutama pada remaja sebagai pengguna terbesar.

Promosi kesehatan berbasis teknologi informasi melalui media sosial dapat berbentuk forum diskusi, 
text-messaging, video messaging, maupun advertisement. Tema-tema yang menjadi fokus antara lain kesehatan reproduksi remaja, seksualitas dan gender, penyakit menular seksual (PMS), kehamilan di usia remaja, dan yang berkaitan lainnya (Aragão, Gubert, Torres, Silva, \& Vieira, 2018). Media sosial mampu memberikan privasi yang lebih tinggi dikarenakan fungsinya yang mampu menjangkau sebagian remaja yang tidak memiliki keinginan untuk berpartisipasi dalam pendidikan seksual secara bertatap muka langsung. Beberapa platform juga memfasilitasi pengiriman pesan secara pribadi sehingga memungkinkan untuk para pengguna berdiskusi secara langsung. Sarana untuk mengubungkan individu dengan dokter, perawat, dan tenaga kesehatan lainnya juga menjadi poin penting yang bertujuan untuk mengedukasi dan berpotensi untuk merujuk pengguna ke layanan kesehatan terdekat. Hal ini jika ditemukan masalah kesehatan atau hanya sekedar melakukan screening bagi yang berisiko (Condran, Gahagan, \& Isfeld-kiely, 2017).

Pada tatanan komunitas, media sosial telah terbukti bermanfaat dalam mempromosikan perilaku sehat pada remaja, juga dapat menghubungkan populasi yang terisolasi secara sosial dengan layanan kesehatan seksual yang aman dan bersifat konfidensial. Ini menunjukkan jika media sosial mampu mempromosikan perilaku seksual yang sehat, serta dapat mengatasi dampak dan stigma negatif yang beredar di masyarakat (Condran, Gahagan, \& Isfeld-kiely, 2017).

Guinta \& John (2018) dalam tulisannya berjudul "Social Media and Adolescent Health" mendeskripsikan manfaat dari penggunaan media sosial sebagai berikut:
1) Kolaborasi dan toleransi, platform media sosia membuat para penggunanya menemukan ide dan pengalaman yang baru. Media sosial mampu memberikan informasi tentang isu terkini, dan membuat remaja belajar untuk memahami dan berempati dengan kelompok yang terisolasi secara social;

2). Akses ke sistem dukungan sosial, media sosial mampu memberikan akses bagi para penggunanya untuk menambah jaringan dan dukungan sosial seperti pada pengguna dengan disabilitas atau dengan penyakit tertentu. Manfaat lain dari media sosial termasuk diantaranya menghindari stigmatisasi, mengakses sumber bantuan, dan mendapat informasi;

3) Komunikasi dan promosi kesehatan, remaja melalui media sosial dapat mencari informasi kesehatan secara online, termasuk informasi dengan topik yang sensitif, seperti masalah seksual dan kesehatan reproduksi. Remaja merupakan populasi dengan pemanfaatan layanan kesehatan yang rendah, untuk itu media sosial memberikan peluang bagi remaja untuk terlibat aktif secara online baik melalui forum diskusi maupun fitur pesan khusus. Media sosial juga mampu meningkatkan status kesehatan remaja dengan menganjurkan perilaku sehat seperti berhenti merokok dan diet sehat;

4) Peningkatan harga diri dan wellbeing, umpan balik positif yang didapatkan melalui media sosial mampu meningkatkan harga diri remaja. Gonzales \& Hancock (2011) dalam penelitiannya menemukan jika keterlibatan remaja dengan suatu komunitas di media sosial dikatkan dengan peningkatan status kesejahteraannya (positive well-being). Media sosial menawarkan alternatif berkomunikasi dengan cara lain, 
menyediakan komunitas pendukung secara virtual, dan membuat dampak positif bagi remaja terutama yang kurang mampu menjalin interaksi secara sosial (social skill). Pada tabel 1 di bawah ini akan dipaparkan rincian hasil jurnal pilihan utama pada studi literatur ini

Tabel 1. Rincian Hasil Jurnal Pilihan Utama untuk Studi Literatur

\begin{tabular}{|c|c|c|c|c|}
\hline $\begin{array}{c}\text { Penulis dan } \\
\text { Tahun }\end{array}$ & Judul & $\begin{array}{c}\text { Desain } \\
\text { Penelitian }\end{array}$ & Sampel & Hasil \\
\hline $\begin{array}{l}\text { Bull et al, } \\
2012\end{array}$ & $\begin{array}{l}\text { Social Media-delivered } \\
\text { Sexual Health } \\
\text { Intervention: A Cluster } \\
\text { randomized Controlled } \\
\text { Trial }\end{array}$ & $\begin{array}{l}\text { Randomized } \\
\text { (Cluster } \\
\text { RCT) }\end{array}$ & $\begin{array}{l}1.578 \\
\text { partisipan } \\
\text { usia } 16-25 \\
\text { tahun }\end{array}$ & $\begin{array}{l}75 \% \text { partisipan menyelesaikan } \\
\text { setidaknya satu kali follow-up. Dalam } \\
\text { jangka waktu } 2 \text { bulan dilaporkan ada } \\
\text { peningkatan } \quad \text { signifikan dalam } \\
\text { pemakaian kondom sebagai } \\
\text { pencegahan PMS }(68 \% \text { pada intervensi } \\
\text { grup vs } 56 \% \text { pada kontrol grup, } p= \\
0.04)\end{array}$ \\
\hline $\begin{array}{l}\text { Pfeiffer et } \\
\text { al, } 2014\end{array}$ & $\begin{array}{l}\text { The Use of Social Media } \\
\text { among Adolescents in } \\
\text { Dar es Salaam and } \\
\text { Mtwara, Tanzania }\end{array}$ & $\begin{array}{l}\text { Mixed- } \\
\text { Methods }\end{array}$ & $\begin{array}{l}60 \\
\text { partisipan } \\
\text { usia 15-19 } \\
\text { tahun }\end{array}$ & $\begin{array}{l}\text { Facebook merupakan media sosial } \\
\text { paling populer yang digunakan remaja. } \\
\text { Remaja memiliki ketertarikan terhadap } \\
\text { topik kesehatan reproduksi melalui } \\
\text { interaksi yang menyenangkan, humoris, } \\
\text { dan adanya peran role model yang } \\
\text { merefleksikan tren yang up-to-date. }\end{array}$ \\
\hline
\end{tabular}

\begin{tabular}{|c|c|c|c|c|}
\hline $\begin{array}{l}\text { Veale et al, } \\
2015\end{array}$ & $\begin{array}{l}\text { The use of Social } \\
\text { Networking Platforms } \\
\text { for Sexual Health } \\
\text { Promotion: Indentifying } \\
\text { Key Strategies for } \\
\text { Successful User } \\
\text { Engagement }\end{array}$ & $\begin{array}{l}\text { Non- } \\
\text { randomized } \\
\text { Intervention }\end{array}$ & $\begin{array}{l}60 \text { akun } \\
\text { facebook } \\
\text { dan } 40 \text { akun } \\
\text { twitter yang } \\
\text { mempromo- } \\
\text { sikan } \\
\text { kesehatan } \\
\text { reproduksi }\end{array}$ & $\begin{array}{l}\text { Akun profil yang mampu menjangkau } \\
\text { populasi pengguna yang lebih besar } \\
\text { adalah akun yang aktif dalam } \\
\text { melakukan promosi kesehatan. } 10 \text { akun } \\
\text { profil peringkat teratas membuat } \\
\text { posting/tweets secara berkala ( } 46 \\
\text { postingan.124 tweets/bulan); dengan } \\
\text { mendorong interaksi melalui unggahan } \\
\text { pertanyaan, unggahan multimedia, } \\
\text { keterlibatan selebriti. }\end{array}$ \\
\hline
\end{tabular}

\begin{tabular}{|c|c|c|c|c|}
\hline $\begin{array}{l}\text { Chu et al, } \\
2015\end{array}$ & $\begin{array}{l}\text { Promoting Sex } \\
\text { Education among } \\
\text { Teenagers Through an } \\
\text { Interactive Game: } \\
\text { reasons for Success and } \\
\text { Implications }\end{array}$ & $\begin{array}{l}\text { Non- } \\
\text { randomized } \\
\text { Intervention }\end{array}$ & $\begin{array}{l}788 \text { murid } \\
\text { sekolah usia } \\
12-16 \text { tahun }\end{array}$ & $\begin{array}{l}\text { Promosi kesehatan reproduksi melalui } \\
\text { game dinilai efektif dan menerima } \\
\text { respon yang baik. Adanya peningkatan } \\
\text { pengetahuan dan sikap setelah bermain } \\
\text { game. Partisipan mendeskripsikan } \\
\text { promos kesehatan melalui game } \\
\text { sebagai sesuatu yang "menarik", } \\
\text { "interaktif", dan "real-to-life". }\end{array}$ \\
\hline $\begin{array}{l}\text { Aragao et al, } \\
2017\end{array}$ & $\begin{array}{l}\text { The Use of Facebook in } \\
\text { Health Education: } \\
\text { Perceptions of }\end{array}$ & $\begin{array}{l}\text { Qualitative } \\
\text { Study }\end{array}$ & $\begin{array}{l}96 \\
\text { partisipan } \\
\text { usia remaja }\end{array}$ & $\begin{array}{l}\text { Penggunaan media sosial facebook } \\
\text { berkontribusi terhadap pendidikan } \\
\text { kesehatan reproduksi pada remaja }\end{array}$ \\
\hline
\end{tabular}




dengan cara yang interaktif,
menyenangkan, dan topik yang
dibicarakan tidak lagi menjadi sesuatu
yang tabu atau memalukan. Serta
memotivasi remaja untuk mengakses
layanan kesehatan dengan
meningkatkan bonding antara perawat
sekolah dengan remaja.

\section{PEMBAHASAN}

Studi ini menggambarkan kemajuan teknologi informasi berupa media sosial yang berpotensi digunakan sebagai media promosi kesehatan reproduksi di kalangan remaja. Dalam beberapa penelitian yang telah dilakukan, facebook menjadi media yang paling banyak digunakan, hal ini dikarenakan facebook memiliki user/pengguna terbanyak di seluruh dunia.

Penelitian secara kualitatif yang dilakukan oleh Aragao et al (2018) pada 96 remaja menggambarkan jika media sosial facebook berkontribusi pada pendidikan kesehatan reproduksi remaja dengan cara yang lebih interaktif, menyenangkan, dan praktis. Remaja pada penelitian ini juga mengungkapkan jika berdiskusi mengenai topik seksualitas tidak lagi menjadi sesuatu yang tabu untuk dibicarakan dengan sebayanya ataupun perawat. Edukasi dengan cara ini juga dapat memotivasi para remaja untuk meningkatkan akses ke layanan kesehatan dengan meningkatkan bonding antara remaja dengan tenaga kesehatan, dalam hal ini adalah perawat sekolah. Hal ini menyiratkan jika interaksi secara online melalui platform media sosial lebih disukai para remaja dibandingkan dengan pendidikan kesehatan secara formal yang dilakukan di ruang kelas. Strategi dengan pendekatan ini dapat digunakan oleh perawat dalam melakukan intervensi berupa pendidikan dan promosi kesehatan kepada remaja terutama jika berkaitan dengan isu yang bersifat tabu, mitos, ataupun berkaitan dengan keyakinan tertentu.

Penelitian lain yang dilakukan oleh Erin et al (2019), berfokus pada pengaruh media digital pada pengetahuan, sikap, dan perilaku terkait kesehatan reproduksi remaja usia 13-24 tahun. Dari observasi yang dilakukan, didapatkan hasil yang menarik yang menunjukkan jika program/strategi berbasis media digital dikembangkan dari teori dan model perubahan perilaku dan terbukti efektif terlepas dari jenis media digital apa yang digunakan. Dalam pengembangan intervensi keperawatan yang berfokus pada promosi kesehatan, telah dikenal juga beberapa teori/model perubahan perilaku yang digunakan sebagai dasar dalam membuat rancangan intervensi pada tatanan individu, kelompok, maupun komunitas. Dalam hal ini perawat dapat mengeksplorasi strategi atau media yang dapat digunakan untuk promosi kesehatan reproduksi pada remaja dengan menggunakan media sosial dan dikaitkan dengan beberapa teori atau model yang telah ada.

$$
\text { Meskipun demikian, }
$$
pemanfaatan teknologi dan informasi yang semakin pesat ini tidak selalu menjamin keberhasilan dari setiap fungsinya. Untuk setiap intervensi yang menggunakan media sosial sangatlah penting untuk memerhatikan aspek kualitas dan memiliki konten yang berbasis bukti (Evidence-Based). 
Sebagai bagian yang tidak terlepas dari remaja dalam kehidupan sehariharinya, media sosial memiliki fungsi unik dalam menyediakan ruang interaksi sosial dengan cara yang menyenangkan, yang dapat dimanfaatkan dalam memberikan pendidikan kesehatan reproduksi yang terarah dan dimediasi oleh tenaga kesehatan, khususnya dalam hal ini adalah perawat.

\section{KESIMPULAN}

Beberapa studi menggunakan promosi kesehatan reproduksi pada remaja sebagai strategi intervensi tunggal maupun kombinasi dengan intervensi yang lain. Hampir semua studi menunjukkan hasil yang efektif dari media sosial sebagai media promosi kesehatan untuk meningkatkan pengetahuan, sikap, dan perilaku kesehatan pada remaja yang berkaitan dengan kesehatan reproduksi. Hal ini menjadi strategi yang dapat digunakan oleh tenaga kesehatan termasuk perawat dalam meningkatkan pelayanan dan mengembangkan media promosi kesehatan terutama bagi remaja.

Penelitian selanjutnya dapat difokuskan pada penggunaan teknologi informasi berupa media sosial dalam jangka panjang serta pengaruhnya pada level preventif, kuratif, dan rehabilitatif terhadap masalah kesehatan reproduksi pada remaja.

\section{DAFTAR PUSTAKA}

Aragão, J. M. N., Gubert, F. do A., Torres, R. A. M., Silva, A. S. R. da, \& Vieira, N. F. C. (2018). The use of Facebook in health education: perceptions of adolescent students. 71(2), 265272.

Asosiasi Penyelenggara Jasa Internet
Indonesia (APJJI). (2018). Jakarta: MarkPlus.

Bull SS, Levine DK, Black SR, Schmiege SJ, Santelli J. Social media-delivered sexual health intervention: a cluster randomized controlled trial. Am J Prev Med 2012; 43: 467-74.

Byron, P., Albury, K., \& Evers, C. (2013). "It would be weird to have that on facebook": Young people's use of social media and the risk of sharing sexual health information. Reproductive Health Matters, 21(41), 35-44. https://doi.org/10.1016/S09688080(13)41686-5.

Chu SKW, Kwan ACM, Reynolds R, Mellecker RR, Tam F, Lee G, et al. Promoting sex education among teenagers through an interactive game: reasons for success and implications. Games Health J 2015; 4: 16874.

Condran, B., Gahagan, J., \& Isfeldkiely, H. (2017). A scoping review of social media as a platform for multi-level sexual health promotion interventions. 26(1), 26-37, https://doi.org/10.3138/cjhs.261A1.

Dunne, A., Mcintosh, J., \& Mallory, D. (2014). Adolescents, Sexually Transmitted Infections, and Education Using Social Media: A Review of the Literature. TJNP: The Journal for Nurse Practitioners, 10(6), 401-408.e2. https://doi.org/10.1016/j.nurpra.2 014.03.020.

Erin, W., Green, C., Debattista, J., Somerset, S., \& Adem, S. (2019). New digital media interventions for sexual health promotion among young people: $a$ systematic review. 101-123.

Gabarron, E., \& Wynn, R. (2016). Use 
of social media for sexual health promotion: a scoping review. $1(3)$.

Golden, S.D., \& Earp, J.A. (2012). Social ecological approaches to individuals and their contexts: twenty years of health education \& behavior health promotion interventions.Health Education \& Behavior, 39(3), 364-372. Medline:22267868 http://dx.doi.org/

Gold, J., Pedrana, A. E., Sacks-Davis, R., Hellard, M. E., Chang, S., Howard, S., ... Stoove, M. (2011). A systematic examination of the use of online social networking sites for sexual health promotion. BMC Public Health, 11, 583.

Guinta, M. R., \& John, R. M. (2018). Social Media and Adolescent Health. 44(4).

Lelutiu-Weinberger, C., Pachankis, J. E., Gamarel, K. E., Surace, A., Golub, S. A., \& Parsons, J. T. (2015). Feasibility, Acceptability, and Preliminary Efficacy of a Live-Chat Social Media Intervention to Reduce HIV Risk Among Young Men Who Have Sex With Men. AIDS and Behavior, 19(7), 1214-1227. https://doi.org/10.1007/s10461014-0911-z

Pascoe, C.J. (2011). Resource and risk: Youth sexuality and new media use.Sexualiy Research and Social Policy, 8(1), 5-17. Retrieved from http://link.springer.com/journal/1 3178

Pfeiffer, C., Kleeb, M., Mbelwa, A., \& Ahorlu, C. (2014). The use of social media among adolescents in Dar es Salaam and Mtwara, Tanzania The use of social media among adolescents in Dar es Salaam. RHM, 22(43), 178-186.
https://doi.org/10.1016/S0968-

8080(14)43756-X

Reid Chassiakos, Y., Radesky, J., Christakis, D., Moreno, M., \& Cross, C. (2016). Children and adolescents and digital media. Pediatrics doi:10.1542/peds.2016.2593

Ressler, P.K., \& Glazer, G. (2011). Legislative: Nursing's engagement in health policy and healthcare through social media. The Online Journal of Issues in Nursing, 16(1). Retrieved from http://www.nursingworld. org/MainMenuCategories/ANAM arketplace/ANAPeriodicals/OJIN/ TableofContents/Vol-162011/No1-Jan-2011/HealthPolicy-and-Healthcare-ThroughSocial-Media.htm

SDKI. (2017). Survei Demografi Kesehatan Indonesia: Kesehatan Reproduksi Remaja. Jakarta: BPS

Todaro, E., Silvaggi, M., Aversa, F., Rossi, V., Nimbi, F. M., Rossi, R., \& Simonelli, C. (2018). Are Social Media a problem or a tool? New strategies for sexual education ₹. Sexologies, 27(3), e67-e70.

https://doi.org/10.1016/j.sexol.20 18.05.006

Queiroz, M. V. O., Lucena, N. B. F. de, Brasil, E. G. M., \& Gomes, I. L. V. (2011). Cuidado ao adolescente na atenção primária: discurso dos profissionais sobre $o$ enfoque da integralidade TT Care to adolescents in primary assistance: professionals' discourse about the focus of comprehensiveness. Rev. RENE, 12(n.esp), 1036-1044. Retrieved from

http://www.revistarene.ufc.br/revi sta/index.php/revista/article/down load/333/pdf 
Veale HJ, Sacks-Davis R, Weaver ER, Pedrana AE, Stoove' MA, Hellard ME. The use of social networking platforms for sexual health promotion: identifying key strategies for successful user engagement. BMC Public Health 2015; 15: 85

We Are Social \& Hootsuite. (2018). Digital 2018: Essential Insights Into How People Around The World Use The Internet, Mobile Devices, Social Media, and ECommerce. We Are Social \& Hootsuite, 76. Retrieved from https://es.slideshare.net/DataRepo rtal/digital-2019-argentinajanuary-2019v01?from_action=save 